\title{
The Online Use of Language for Communication in Tourist Village Community of Pujon Kidul Malang
}

\author{
Ismatul Khasanah ${ }^{1}$, Esti Junining ${ }^{2}$, Roosi Rusmawati ${ }^{3}$, Khilmi Mauliddian $^{4}$ \\ \{ismatulkh@ub.ac.id ${ }^{1}$, esti@ub.ac.id ${ }^{2}$,roosi_rusmawati@ub.ac.id ${ }^{3}$, khilmi.mauliddian@ub.ac.id $\left.{ }^{4}\right\}$ \\ Universitas Brawijaya, Indonesia ${ }^{1,2,3,4}$
}

\begin{abstract}
The current language phenomenon is developing under the influence of situations and conditions that humans always execute, whether consciously or unconsciously. It is undoubtedly that the impact of human behavior on their language system and language choice leads to an inseparable bond between the former and its respective socio-cultural environment. This study aims to acknowledge the manifestation of language choice performed by the community of Tourist Village Pujon Kidul, Malang when they interact online, especially in the domain of social networking. The method utilized in this study relies on a qualitative design to portray the general depiction of a certain occurrence without any given treatment. The technique used is threefold; interviewing, note-taking, and recording to document the community interaction within the domain of online or social media, such as Facebook and Instagram administered by Komunitas Desa Wisata Pujon Kidul Malang (Tourist Village Pujon Kidul Malang Community). What motivates such an approach is the concern to prevent Covid-19 from worsening should there be field research, therefore online-based research data are deemed significant. This study targets the fundamental policy of the use of language in a specific community within the domain of online media while taking into account the values of local culture. The result shows that the manifestation of language choice portrayed in social media such as Facebook and Instagram are of four categories: Indonesian, Javanese, English, and a mix of the three languages; Indonesian-Javanese, Indonesian-English, and Javanese-Indonesian. Meanwhile, the interaction process is divided into three; the language use, the status context, and the dialogue room.
\end{abstract}

Keywords: Online Media, Community, Desa Wisata Pujon Kidul, Sociolinguistics

\section{Introduction}

The current language phenomenon is developing under the influence of situations and conditions that humans always execute, whether consciously or unconsciously. It is undoubtedly that the impact of human behavior on their language system and language choice leads to an inseparable bond between the behavior and its socio-cultural environment. This stance is in conjunction with what Mardikantoro [1] states, that a language system must be heavily influenced by their respective socio-cultural factor. That being the case, sociolinguistics exists as the fundamental sine qua non to uncover any current linguistic phenomenon in a specific community.

Ngalim [2] claims that a scholarly study concerning the use of varied, functional, and interdisciplinary language associated with a linguistically-conscious, heterogeneous society is what makes sociolinguistics a branch of linguistics. In other words, language use does not 
involve linguistic aspects only, but non-linguistic factors need to be evaluated as well. Thus, there must be circumstantial events, situations, or conditions that predispose interactions between conversation partners, as a definite proof that the manifestation of language use is inseparable from an external factor: the background context. Accordingly, then, sociolinguistics studies the relationship between an interlocutor and his/her partner, as well as the languages are spoken and their variants, the linguistic and non-linguistic aspects involved in the language use, and various language forms which are actively used and well-maintained within a specific society.

One of the linguistic phenomena within the discussion of sociolinguistics is the language choice, where it emerges in either a bilingual or multilingual community. Chaer and Agustina [3] state that bilingualism describes the ability to use two languages, while multilingualism allows a person to use two or more languages with their partners interchangeably. Another description of multilingualism involves a broader spectrum in which a community can perform several languages at once [4]. In a nutshell, the process of language choice within a society can be fulfilled using two approaches, either through the former (bilingualism) or the latter (multilingualism), along with the impact of social conditions underlying their choice of language.

In conjunction with the previous statement, an interesting research object as it encompasses the language choice of Desa Wisata Pujon Kidul Malang (Tourist Village Pujon Kidul Malang) community in online media. Indeed, the vast development of technology and the existence of several social media are effective advertising tools to inform or interact with a wider community, therefore they are positively utilized by the community of Tourist Village Pujon Kidul Malang to easily administer the information of the existing tourist attraction. Previously an ordinary village in the mountain hill, Pujon Kidul is currently an attractive highlight for domestic and international tourists.

This study is the continuation of the previous language choice research within the same domain of tourist destinations at Kampung Warna-Warni Jodipan, Malang [5]. However, there is a slight difference in which this study investigates the online interactions of Tourist Village Pujon Kidul Malang community. The motivation underlying the use of online media as the research object is to prevent the spreading of Covid-19, which is currently escalating worldwide [6] including Indonesia [7]. Using online-based data, not only does this study help the virus prevention but also investigates the recent language phenomena omnipresent in many online interactions. To further delve into this trend, the circumstance of this study is worth investigating, especially concerning the language choice of the community in tourist spots.

The aims of this study are twofold: first, to describe the manifestations of the language choice, and second, to investigate the interaction process of the language choice performed by the community of Tourist Village Pujon Kidul Malang in online media.

Meanwhile, the research questions are of the following: first, how is the manifestation of the language choice performed by the community of Tourist Village Pujon Kidul Malang in online media? Second, how is the process of interaction of the language performed by the community of Tourist Village Pujon Kidul Malang in online media?

Tourist destinations in Malang Regency have been leaning towards productivity gradually. The expansion of tourist sightings is not only dominated by large tourist companies but also by the villagers independently. According to Malang Regency's BPS data, there are approximately 69 tourist highlights recorded which can be visited by domestic and international tourists. The data comprises beaches, waterfalls, temples, as well as food destinations. However, the trend leans towards culture-based tours or tourist villages, which are currently the most popular tourism sites among visitors. 
The emergence of village-based destinations helps elevate the so-called traditional rural areas in the skirts into promising sightseeing spots that are worth competing with cities or modern sites alike. By offering a natural, refreshing atmosphere that is always well-maintained for visitors to escape from the cramped urban lives, tourist villages successfully attract people to come and spend their holiday with family and close friends.

One of the most well-known tourist villages is Kafe Sawah, established in Tourist Village Pujon Kidul, Pujon, Malang, with the absolute location of the village itself at $7^{\circ} 21^{\prime}-7^{\circ} 31^{\prime}$ South latitude and $110^{\circ} 10^{\prime}-111^{\circ} 40^{\prime}$ East longitude astronomically. The village is located in the plateau and is surrounded by hills and mountains with a height reaching $1200 \mathrm{~m}$ above sea level.

Although Pujon Kidul village is often famous for its agritourism concepts such as farming, plantation, and dairy farming, the village can pull out a more inviting, creative concept by offering the beautiful view of greenery as their main attraction for visitors through the establishment of Kafe Sawah [8].

Kafe Sawah is founded through a creative thought process of a group of youth and fellow village administrative to get rid of poverty and unemployment among the youngsters as well as to empower the villagers around. In 2011, the idea was realized through a small patch of café, and as the time went by, the enthusiasm of the visitors motivated the administrator to add other facilities and creativities with the help of the government to turn it into a unique café worth visiting.

This led to the café being officially recognized as 'Kafe Sawah' and was re-established as a family-friendly destination since October $11^{\text {th }}, 2016$. On March $16^{\text {th, }} 2017$, however, Malang Regent residing at that time officially launched the café at last. With an $8000 \mathrm{~m}^{2}$ land size, the café's concept provides an appealing panorama surrounded by mountains and spacious farming area with refreshing, cool air, making it one of Pujon Kidul's mainstays popular among visitors. The facilities include pendopo (Javanese open hall), gazebo, mushola (praying area), toilets, parking area, dining area, and Kafe Sawah's special photo spots. Tourists can also visit a mini flower garden filled with various colorful flowers. To enter this family-friendly spot, they are obliged to pay Rp. 5000,00 that they can exchange with fresh beverages (www.tribunews.com).

To expand its business, the community of Tourist Village Pujon Kidul makes use of online media to promote tourism to a wider audience. Social media such as Facebook Community and Instagram, which are actively utilized by both the community and people, in general, to interact with each other, helps them reach out to tourists from many places to come to Tourist Village Pujon Kidul. The power of both platforms in bringing thousands of people together is an advantage in itself because the community can use them to raise the number of interactions from people who are curious about the existence of Tourist Village Pujon Kidul Malang. Consequently, the interactions recorded in both platforms are worth observing, as - aside from being a functional promotion tool-the interactions themselves can be considered as a rare linguistic phenomenon in online media, especially in the domain of tourism. Therefore, the focus of this study concerns the language choice of the community of Tourist Village Pujon Kidul Malang in online media.

Rahmawati [9] defines online media as a state-of-the-art Internet-based platform where, compared to printed media with more limited access, the information flow is distributed substantially without many obstacles. Users are not only allowed to participate in sharing the information, but they are also able to create their content through blogs and social networking to a wider audience. Online media is also widely known as social media, which refers to how Rulli [10] describes social media as the Internet medium where users can represent themselves as well as interact, cooperate, share, and communicate with others. In short, online or social 
media is Internet-based media where people can interchange, share, and create content within a specific platform of their choice.

Types of social media are described to acknowledge the way those media operate and are not limited to platform developments on the Internet nor smartphone applications. Rulli [10] divides the types of social media into six: 1) social networking that allows their users to interact with each other not only from the textual message but through visual attachments such as realtime photos for personal publication, as well as sharing current trends and information to the public. 2) Blog, where users can upload their daily routines, respect other bloggers, and share links to external webs, information, and others. 3) Twitter, or microblogging, which facilitates the users to write or publish their activity and opinions within 140 limited characters at maximum. 4) Sharing media, such as YouTube, Flick, Photos Bucket, and Snapfish as userfriendly platforms to share various file forms from a document, video, audio, pictures, and others. 5) Social bookmarking where users are offered the convenience of organizing, storing, managing as well as information gathering online. Last but not least, 6) Wiki is a collaborative site where users are engaged together to contribute to building a certain publication. Almost similar to a dictionary or encyclopedia, a wiki provides the audience with definitions, history, as well as book references of a specific word.

Labov [11] states that sociolinguistics relates linguistic study with the society, where the role of interlocutors and their partners are considered significant variables to complement the linguistic aspects of the society. Besides, if the existence of interlocutors is ignored, to a great extent, it means one has narrowed down the essence of the sociolinguistic study itself. It can be concluded then that linguistics and societal reality are two inseparable variables to observe the trending linguistic phenomenon.

Language choice involves the act of choosing a certain language within communication [12]. In other words, language choice can develop as a multilingual society provides codes, dialects, variations, and styles to use in social interaction. Moreover, the phenomenon does not cover linguistic aspects only, but it also includes social, cultural, psychological factors.

Ervins-Tripp [13] mentions there are four main factors influencing language choice in social interaction, inter alia 1) background and situation of interaction, 2) participants of interaction, 3) topic of interaction, and 4) function of interaction. Background and situation of interaction concerns with the time and place - when and where the event takes place - as well as the expressions involved, be it happiness, grieve, or others. Trivial variables such as age, gender, occupation, socio-economic status, the relationship between interlocutors (intimate, casual, or distanced) influence participants of interaction, and the way they choose languages. Not to mention that theme or topic of interaction is a prevalent aspect that also underlies the flow of interaction and participant's language choice. Last but not least, the function of interaction refers to the participants' goal when interacting with each other, for example, to give information, to offer, to refuse, to apply, or to casually converse daily. The aforementioned factors are all significant in influencing an interlocutor's language choice.

There are three previous studies about language choice in society. The first study is conducted by Mardikantoro [1], where qualitative design is employed for descriptive data from written discourses. The study finds out that within their family affairs, Samin community tends to use the three variants of Javanese such as Jawa Ngoko and Jawa Madya/Krama, as well as codemixing and codeswitching the former variant with the latter and vice versa.

A similar qualitative study is conducted by Niswa and Mukhlish [14] where they discover that (1) the linguistic repertoire of the multilingual community in Kemujen consists of: (a) most of the population $(40 \%)$ is only able to speak one language $\mathrm{BJ}(20 \%)$; BB $(15 \%)$; and BM $(5 \%)$, (b) $30 \%$ of the population can speak two languages, either BJ and BB (10\%); BJ and BI (10\%); 
$\mathrm{BJ}$ and $\mathrm{BM}(5 \%)$; $\mathrm{BB}$ and $\mathrm{BI}(5 \%)$ and (c) the rest can speak more than two languages, such as $\mathrm{BJ}, \mathrm{BB}$, and $\mathrm{BI}(15 \%)$; BJ, BB, and BM (10\%); BJ, BB, BM, and BI (5\%). (2) The domain of the language choice in Kemujen includes (a) family, friendship, neighborhood, and daily transaction realms, with $\mathrm{BJ}$ and $\mathrm{BI}$ as the most dominant languages to use, (b) education, religion, and government officials, dominated by BJ and BI. (3) Social variables that affect language choice are (a) education, with $\mathrm{BJ}$ and $\mathrm{BI}$ as the main language (22\%), (b) occupation, with BJ as the most used language (25\%), (c) gender, where BJ is also dominantly used (20\%), and last but not least (d) age, with BJ dominating the interaction between interlocutors (17\%).

Lastly, a study by Khasanah et al. [5] focuses on the choice of language used towards tourists, where the locals tend to lean towards mixed languages or codemixing, for instance by mixing Javanese (either krama or ngoko) with Indonesian. However, interactions using English to international tourists has not been discovered yet, as it is limited to simple greetings and informing directions only.

This study employs the same object focus, the language choice, as the aforementioned previous studies. However, with studies conducted by Mardikantoro [1] and Niswa and Mukhlish [14], the disparity lies in the location, where it focuses on a specific tourist destination community. Meanwhile, as a continuation of the study conducted by Khasanah et al. [5], this study centers around the language choice in online media. In short, this study wants to emphasize the language choice of a tourist destination community within their use of online media.

\section{Research Method}

This study employs qualitative design to provide the audience with a general view of a phenomenon in clarity without the interference of specific treatments to the object of the study. Moleong [15] describes the method as the perfect procedure for attaining descriptive data from either written and spoken discourse as well as the behaviors of the participants observed from the existing phenomenon. This study aims to provide a systematic and factual interpretation of the problem from the data obtained, by presenting, analyzing, and lastly, interpreting the data.

The techniques used in this study are twofold: interview and record. The researchers participated directly in the interaction by listening and recording without involving themselves in the conversation [1]. As the aim of this study is to provide a systematic and factual interpretation of the problem from the data obtained, by presenting, analyzing, and lastly, interpreting the data, the presentation of the data itself was done informally. Also, by referring to Sudaryanto in Kesuma, the analysis can be completed using casual language instead [16].

The timeline of this study spanned from March to July 2020, with the initial expectation that within those months, the data could be successfully obtained. The data was collected through an online media platform such as the Facebook and Instagram accounts of Tourist Village Pujon Kidul Malang community.

Participants of this study involved the community within the interactions found on the Facebook and Instagram accounts of Tourist Village Pujon Kidul Malang community, while the research object focused on their language choice when interacting in those online platforms.

The researchers, as well as the team behind data collection, are the instruments of this study. The team involves themselves in observing the interaction of the community inside the Facebook and Instagram accounts of Tourist Village Pujon Kidul Malang before documenting them. 


\section{Results and Discussion}

The data consists of both status and comments recorded on the Facebook page and Instagram timeline of Tourist Village Pujon Kidul account named Café Sawah Desa Wisata Pujon Kidul. For easier identification, status is symbolized as X, and comments (if available) are represented with A, B, C, and others. This study purposely left out the identity of the people who commented on either Facebook or Instagram to protect both their personal and account privacy. The data provided in this study is in the form of articles, and they have been carefully chosen to suit the contexts of the status written by X (the account administrator) to observe the form of language choice by the users who commented as well as the interaction process. The data is originally retained without any alteration and is identified according to the language used.

\subsection{Language Choice of Tourist Village Pujon Kidul Malang Community in Online Media}

The data presented in the following section is divided based on the timeline of the status, ranging from the year 2018 to 2020 .

\subsubsection{Forms of Language Choice Found on Facebook Fanpage}

a. 2018

Data 1

Context: The location's view (uploaded on March 16, 2018)

X: ketenangan... \#cafesawah

Comments:

A: Suip. Cuocok mantap tempatnya juga kulinernya

$\mathrm{X}$ : trimakasihh... silahkan berkunjung ke cafe sawah

A: Pasti.yg bakal keberapa kali yaaaa....

C: Kapan bs ke sni lagi yaaaa... Naik seru seruan lagi..

D: Siap mbakku....

E: Tertarik ... mhn info menu2 nya apa aja yaa yg dijual

$\mathrm{F}$ : nek ada rezeki cuti bareng mba, pasti tak jak mrono (Kalau ada rizki cuti bersama mbak, pasti saya ajak ke sana)

G: Kpan iso nang tempat iku yo...mbak Laurent Ziea bwa daku donk kesono (Kapan bisa ke tempat itu ya, mbak Laurent Ziea bawalah saya ke sana)

H: Tertarik...

I: nasi ampok bikin kngen lagi...

$\mathrm{J}$ : Ikan asinnya ngangeni...

$\mathrm{X}$ : hehe monggo pinarak mass (hehe silakan singgah mas)

K: Ayah Kriztiawan Septa hmmm kpan kita kesini?

L: Insya Allah, liat menunya apa liat tempatnya nda

$\mathrm{K}$ : Liat kabeh (melihat semua)

We can notice from the data that the writer $\mathrm{X}$ used the word ketenangan 'serenity' in Indonesian which describes the atmosphere of the café at that specific time. Meanwhile, the hashtag \#cafesawah refers to the name of the place. Instead of using the word kafe in Standard 
Indonesian as the result of it being a loanword, the writer opted for the English term 'cafe'. We can also imply that the word ketenangan in the caption represents the meaning of the photo itself, raising various responses by Facebook users in the comment section. It is found that there are three forms of language choice in this interaction, which are Indonesian, Javanese, and a mix of Javanese and Indonesian.

There is only one comment using Standard Indonesian tertarik 'interested' written by user $\mathrm{H}$, and on the contrary, eleven comments use Non-Standard Indonesian, which is represented in the interaction between user A and user Y. The comments are as follows:

A: Suip. Cuocok. Mantap tempatnya juga kulinernya (Nice. Fitting. The place and foods are extraordinary) which was replied by $\mathrm{Y}$ :

Y: Trimakasihh.. silahkan berkunjung ke cafe sawah (Thank you... see you again on your next visit) and was countered by A:

A: Pasti.yg bakal keberapa kali yaaaa.... (Surely. How many times has it been already...) Other comments between user $\mathrm{C}$ and $\mathrm{D}$ are as follows:

C: Kapan bs ke sni lagi yaaaa... Naik seru seruan lagi.. (Wondering when's the right time to come back... driving with so much fun...) Which was replied by D:

D: Siap mbakku... (I'm ready, Sis...)

There are also some comments related to the menu:

E: Tertarik ... mhn info menu2 nya apa aja yaa yg dijual. (I'm interested... please provide more information about the dishes)

I: nasi ampok bikin kngen lagi... (The Nasi ampok brings back memories...)

$\mathrm{J}$ : Ikan asinnya ngangeni.. (I sure miss the salted fish...)

A short interaction between $\mathrm{K}$ and $\mathrm{L}$ discussing about their visit and the menu:

K: Ayah Kriztiawan Septa hmmm kpan kita kesini? (Dad Kriztiawan Septa when will we go there?)

L: Insya Allah, liat menunya apa liat tempatnya nda (Insya Allah, do you want to see the menu or the place?)

$\mathrm{K}$ : Liat kabeh (All of them)

The use of Non-Standard Indonesian in these comments can also be understood as a language form without paying attention to the grammatical rules.

Whereas the form of Javanese language can only be observed from one sentence only in a comment written by X:

$\mathrm{X}$ : Hehe monggo pinarak mass (Hehe please pay us a visit next time, Sir)

The form of Non-Standard Indonesian and Javanese can be seen from three comments by different users:

K: Liat kabeh (All of them)

F: nek ada rezeki cuti bareng mba, pasti tak jak mrono (If we can have a day off, I will surely take you there)

G: Kpan iso nang tempat iku yo...mbak Laurent Ziea bwa daku donk kesono (When can I stop by that place... Sis Laurent Ziea please take me there) 
Data 2

Context: Promoting an activity (uploaded on April 3, 2018)

$\mathrm{X}$ : (no caption)

Comments:

A: Selamat

B: sukses selalu

C: Mantap

D: Pujon kidul ada rt 11 rw 07 g ya tlg infoya

E: Moga tambah jaya slalu

The writer X chose Javanese as depicted from the word monggo meaning 'silahkan' in Indonesian (which can be roughly translated as 'please drop by' in English). We can also observe the mix of three languages - Javanese, Indonesian, and English - in the caption. An English phrase 'free selfie', or bebas swafoto in Indonesian, can also be found inside the photo. The comments, however, are all in Indonesian, where A, B, C, D, and E complimented and congratulated the activity promoted by $\mathrm{X}$.

Data 3

Context: Introducing the guides (uploaded on April 22, 2018)

$\mathrm{X}$ : crew parkir cafe sawah...

Comments:

(no comments from Facebook users)

The data shows that the caption written by X crew parkir cafe sawah 'café sawah's parking crews' is a mixed of English and Indonesian, where crew was used instead of 'regu', the Indonesian equivalence. No comments observed from this status, leaving only the caption instead.

Data 4

Context: Announcement (uploaded on July 26, 2018)

$\mathrm{X}$ :

Comments:

A: Ayok ksana
B: Up

The data shows a photo of an announcement uploaded by $\mathrm{X}$ with the writings " $U N T U K$ MINGGU TGL 12 AGUSTUS CAFE SAWAH TUTUP TOTAL KARENA ADA KIRAB BUDAYA/ KARNAVAL", "Café Sawah will be closed on Sunday, August 12 due to cultural festival/carnivals". The writer of the announcement used a mixed of Standard Indonesian and English and paid attention to the grammatical rules as well, where the use of English can be observed from the word café. 
Moreover, there are only 2 comments from Facebook users A and B. A used Non-Standard Indonesian in ayok ksana 'let's go there', meanwhile B wrote a short 'up' in English as a means to promote the announcement to a wider audience.

b. 2019

Data 5

Context: Customer service (uploaded on January 20, 2019)

\section{X: Kita harus mengutamakan wisatawan/pengunjung}

\section{Comments:}

\section{A: tambah lagi tempat untuk berteduh bila hujan pengunjung. \\ B: Josss}

From the data, $\mathrm{X}$ chose to use Indonesian when writing kita harus mengutamakan wisatawan/pengunjung 'we must prioritize our visitors/tourists' consisting of customer services they offered with some additional notes. The status received two responses, which were all written in Indonesian.

The comment given by A tambah lagi tempat untuk berteduh bila hujan pengunjung 'please provide more shelters for visitors to go to when raining' consisted of an advice for the café's administrator to add more places to take shelter. Whereas the comment written by B josss 'nice' served as a compliment for the service offered by the café depicted in the status.

Data 6

Context: Closing announcement (due to COVID-19) (uploaded on July 7, 2020)

$\mathrm{X}$ :

Comments:
A: Up
B: Sudah buka belum?
C: Kira2 bukanya kpn nggeh
D: $O k$

The data consists of a photo uploaded by the writer $X$ with a writing in a mixed of Indonesian and English: Cafe sawah sementara masih tutup, untuk bukanya menunggu kabar selanjutnya 'Café Sawah is temporarily closed, we will update you once we are open'. Although it is a mixed of Indonesian and English, there is only one English word written, which is 'café'. Considering the time of the upload, the content of the writing is about a closing announcement due to Covid-19 aimed for future visitors. Furthermore, looking at the comments directed to X's upload, the users' language choice varied around English, Indonesian, and a mixed of Indonesian and Javanese

English was seen used in two comments written by A ('up') and D ('ok'), while there is only one comment using Indonesian written by B "sudah buka belum?" 'has it opened already?' to confirm whether the café was still closed or not. Lastly, a comment using a mixed of Indonesian and Javanese was written by C "kira2 bukanya kpn nggeh" "can you estimate when 
the café will open' to also confirm about the café's opening. The word "nggeh" 'yes' is the only Javanese form found in this comment.

Data 7

Context: Information of the café's re-opening in the new-normal era (uploaded on August 20, 2020)

X: Cafe sawah sudah buka lagi, silahkan datang dan nikmati suasana cafe sawah dgn mematuhi peraturan pemerintah, menjalankan protokol kesehatan

Comments:

A: Kalau anak2 bayar ngk masuknya pak

The data shows that the writer $\mathrm{X}$ chose to write the caption using a mixed of Indonesian and English. The caption, "Cafe sawah sudah buka lagi, silahkan datang dan nikmati suasana cafe sawah dgn mematuhi peraturan pemerintah, menjalankan protokol kesehatan" "Café Sawah has reopened, please drop by and enjoy the refreshing atmosphere at Café Sawah by always complying to government's health protocols', informed the reopening of the café and advised them to always comply to government's health protocols when relaxing at Café Sawah. There is only one English word appeared in the caption, which is café.

The upload received only one response from user A, where they used Indonesian when writing the comment. The comment, "Kalau anak2 bayar ngk masuknya pak" 'Do children also need to pay entrance fee, Sir', meant to confirm whether children are obliged to pay for tickets when visiting Café Sawah.

\subsubsection{Forms of Language Choice Found on Instagram}

a. 2018

Data 1

Context: Appeal to tourists (uploaded on October 17, 2018)

X: Begitu indahh...

Comments:

A: Wah, jdi kangen mau ke situ lgi...

B: mantap

C: Kmrn tnggal 4 sya ksni, study banding. Tpi blm puas

D: HTM nya berapa yaa sekarg...?

E: Pujon Kidul mgkn kren

F: Agendakan kesini yoo

The form of X's language choice can be observed from the writing in the photo and the caption they uploaded on the Instagram account. X wrote begitu indahh 'so dazzling', whereas the photo showed a list of notices the visitors must obey when visiting the café: Jadilah Wisatawan Bertanggungjawab, Tidak Menginjak Tanaman, Tidak buang sampah sembarangan, Tidak Membawa Miras, Tidak Membawa Sajam, Tidak Memetik Bunga 'As visitors, please be responsible for your own doings by: not stepping on the flowers, littering, 
bringing liquors and weapons, as well as plucking the flowers'. Both the captions and the writing in the photo were all written in Indonesian.

Regarding the comments, it is observed that from 6 responses, 5 users used Indonesian and the other one used Javanese when writing their comments. A wrote Wah, jdi kangen mau ke situ lgi... 'Wow, this sure makes me want to go back' to express their longing feeling towards the place. B complimented the café by commenting mantap 'nice'. C responded the upload by writing Kmrn tnggal 4 sya ksni, study banding. Tpi blm puas 'I dropped by on the last $4^{\text {th }}$ for a comparative study, but I wasn't satisfied' to narrate their experience when visiting the café and felt unsatisfied by the last visit. D questioned the entrance fee by writing HTM nya berapa yaa sekarg...? 'How much is the entrance fee now?'. Last but not least, E appraised the café by commenting Pujon Kidul mgkn kren 'Pujon Kidul is certainly cool'. A comment using Javanese was written by F Agendakan kesini yoo 'Let's plan a visit together' to invite their friends to go there together. Here, F used a Javanese article yoo which can also be translated roughly as ' $y a$ (yes)' in Indonesian and 'let's' in English.

b. 2019

Data 2

Context: Profile Video (uploaded on May 28, 2019)

\section{X: COME IN DESA WISATA PUJON KIDUL "SEKATPENATMU"}

Comments:

A: As I had a look at your account, I liked your recent photos more very good B: Bella foto!

According to the data, we can identify X's language choice as they used a mixed of English and Indonesian when writing the caption COME IN DESA WISATA PUJON KIDUL "SEKATPENATMU" complementing the visual audio that presented the destination profile to attract Instagram users to engage in the post. The phrase 'come in' is the form of English in the caption, while the rest is all in Indonesian.

There are two responses on X's upload, where one of them used English and the other one used Indonesian. The English comment was written by A as I had a look at your account, I liked your recent photos more (c) very good to compliment and appraise the photos uploaded by $\mathrm{X}$, whereas B used Indonesian when writing Bella foto! 'Bella, photo!' to invite someone to take some photos when visiting the destination.

Data 3

Context: Promotion (uploaded on August 16, 2019)

$\mathrm{X}$ : Yang sayur yang sayurrr,,,,, sayur nya yuk gaesss yang mau sayur segar,harga serba 5 k aja bisa petik juga ,,

Comments:

A: Besok sore msh adakah petik sayurnya min? $5 \mathrm{k}$ dpt brp $\mathrm{kg}$ ?

According to the data, the writer X used Indonesian in the caption Yang sayur yang sayurr,,,,, sayur nya yuk gaesss yang mau sayur segar,harga serba $5 k$ aja bisa petik juga ,,, 'Who wants vegetables? We provide fresh vegetables for five thousand rupiahs; you can also 
pick them if you want' to complement the poster uploaded about the price list for vegetable selffarming service. Only one response observed in the data where the user A used Indonesian to ask for the promotion offered by X: Besok sore msh adakah petik sayurnya min? $5 \mathrm{k} \mathrm{dpt} \mathrm{brp} \mathrm{kg}$ ? 'Will the service be available tomorrow evening? How much kilogram we can get for five thousand rupiahs?'

c. Tahun 2020

Data 4

Context: Information regarding the café's temporary closing (uploaded on June 22, 2020)

$\mathrm{X}$ : Info e lurd

Comments:

\section{A: Kapan buka minn}

B: Kapan buka min

C: Masih tutup gaisss, ini yg wktu itu mau kita tuju y kaannn

D: sdh buka blm

E: Kapan bukanya min

F: Kpn buka e

G: Kapan buka?

In writing the caption, $\mathrm{X}$ used a mixed of Javanese and Indonesian to complement the information depicted in the photo regarding the cafe's temporary closing. Only one Indonesian word info 'info' observed from the caption and the rest, e lurd (roughly translated as 'guys') is in Javanese.

Meanwhile, the forms of language choice by those who commented on the upload can be divided into three: five comments used Indonesian, one comment used a mixed of Indonesian and English, and the other one used a mixed of Indonesian and Javanese.

Those who commented using Indonesian, A, B, D, E, and G all questioned the same issue; when the tourist destination would reopen again. $\mathrm{C}$, who commented using a mixed of Indonesian and English Masih tutup gaisss, ini yg wktu itu mau kita tuju y kaannn 'They're still closed guys, this is the one we wanted to go to, right?', is also concerned about the place's reopening, similar to the former comments. Last but not least, a comment by F using a mixed of Indonesian and Javanese Kpn buka e 'when will it reopen' which is also very similar to the other comments, however, F used a form of Javanese language ' $e$ ' which is also a dialectal article.

Data 5

Context: Tour's Reopening Information (uploaded on August 14, 2020)

X: Selamat mlm gaes

Untuk CAFE SAWAH MINGGU 16 AGUSTUS 2020 udah mulai buka kembali..

Tetep patuhi protokol kesehatan ya

Jaga jarak dan Pakai masker

\#cafesawah

\#newnormal

\#amazingmalang 
\#amazingpujon

\#malan

Comment:

A: Alhamdulillah kebetulan udahnyampai malang .. bsk pagi mau $k$ sna... Jos banget. ... Makasih... ini yg d tunggu tunggu

B: Alhamdulilah ud buka kesini jg ta

$\mathrm{C}$ : piye ngene iki per? :)

D: Minggu kmarin ke malang dn tujuan utama cafe sawah, ternyata tutup kecewa banget. Malah diarahkan ke bukit nirwana, coba-coba donk kesana. Eh malah semakin nyesel

E: Dah buka gais

F: Ehh bukaa

G: Deket e coban rondo kan iku

$\mathrm{H}$ : Skuy beb direyen

I: kawit d bukak

$\mathrm{J}$ : Horeeee akhrnya udh buka setelah lama penantian

$\mathrm{K}$ : sdh buka wuk

L: Yess, wis buka. Sesuk rene

M: Apes kemren tgl 07 ke malang sdh booking hotel 2 hr eh ternyata pada tutup

$\mathrm{N}$ : kangen nasi jagungnyaaaaa

O: kilo golek anmu

P: Papa...sini

Q: akhirnya

Referring to the data, $X$ wrote the caption in a mixed of Indonesian and English (see the caption by $\mathrm{X}$ above) related to the reopening of the place. There are 17 responses identified from various Instagram users using different language choice projection in each comment, which can be divided as follows: 8 comments in Indonesian, 3 comments in Javanese, 3 comments in a mixed of Indonesian Javanese, 1 comment in a mixed of Indonesian English, and the last 2 comments in a mixed of Javanese and English.

The elaboration of comments written in Indonesian is detailed as follows. User A commented Alhamdulillah kebetulan udah nyampai malang .. bsk pagi mau $k$ sna... Jos banget. ... Makasih... ini yg d tunggu tunggu 'Alhamdulillah, so glad we've arrived in Malang... We'll drop by tomorrow morning... Really nice... Thank you... This is what we came for' to express their personal gratitude to visit the infamous tourist destination. Whereas D wrote Minggu kmarin ke malang dn tujuan utama cafe sawah, ternyata tutup kecewa banget. Malah diarahkan ke bukit nirwana, coba-coba donk kesana. Eh malah semakin nyesel 'Last Sunday we went to Malang for the purpose of visiting Café Sawah, but it's closed... very disappointed. Someone directed us to Bukit Nirwana (another tourist spot), so we might as well try. But it quickly turned worse' as a drawback because the café was closed at the time. F and J both conveyed their excitement of the café reopening by writing Ehh bukaa 'Ehh it's opened' and Horeeee akhrnya udh buka setelah lama penantian 'Hurraaay, after a long awaiting, finally the café's opened'. Next, M showed their personal frustration because they visited the place at the wrong time by writing Apes kemren tgl 07 ke malang sdh booking hotel $2 \mathrm{hr}$ eh ternyata pada tutup 'Unlucky me, going to Malang on the $7^{\text {th }}$ and booking a 2-day room only to find out the café's closed'. A comment by $\mathrm{N}$ kangen nasi jagungnyaaaaa 'I miss their corn rice' entails the 
fact that $\mathrm{N}$ really missed the menu offered by the café. $\mathrm{P}$ commented Papa...sini to invite their friends to go there together, while Q wrote akhirnya 'finally' as a simple statement showing how happy they were that the tourist destination had finally opened.

In addition, there are 3 comments written in Javanese written by $\mathrm{C}, \mathrm{I}$, and $\mathrm{O}$. $\mathrm{C}$ wrote piye ngene iki per? :) (bagaimana ini Per) 'What do you think, Per?' as an invitation towards their friend. A comment by I kawit d bukak (mulai dibuka) 'It has started to open' indicates a good cheer as the café had opened. The last comment in Javanese is written by $\mathrm{O}$ kilo golek anmu (ini yang kamu cari) 'This is what you're looking forward to' to inform their friend about the reopening of the café.

There are also 3 comments written in a mixed of Indonesian and Javanese, such as a comment written by B Alhamdulilah ud buka kesini jg ta 'Alhamdulillah it's already opened again' to convey their happiness as the café reopened, where B used a Javanese article ' $t a$ ' as a dialect feature. Another comment written by G Deket e coban rondo kan iku (dekatnya coban rondo kan itu) 'It's the one near coban rondo, right?' to confirm the precise location of the café, which is near another destination. There are two articles used in this comment: $e$ and $i k u$ (itu) 'it is', which are all dialect features of Javanese. The last comment in this category written by $\mathrm{K}$ sdh buka wuk (sudah buka nak) 'It's opened, kiddo' informs the reopening of the café to their relatives. A Javanese word to address a relative wuk (nak/kak), roughly translated to 'kiddo' in English, appeared in the comment as well.

One comment in a mixed of Indonesian English was written by E Dah buka gais 'It's opened, guys' as a way to let their friends know of the reopening of the destination. The use of gais, a nativised version of 'guys' in English, is an intimate way of addressing close friends.

Last but not least, there are two comments written in a mixed of Javanese English by $\mathrm{H}$ and L. H commented Skuy beb direyen (motor barunya sayang dinaikin) 'Let's ride your new motorcycle there' to ask their friend about the plan to go to the destination with their new motorcycle. An assimilated English word beb 'babe' also appeared as another intimate way to address close friends. Another comment written by L Yess, wis buka. Sesuk rene (Iya, sudah buka, besok ke sini) 'Yes, they're opened, tomorrow I'll go there' expresses their eagerness to visit the destination. The use of English is also projected in this comment by the addition of the word yess 'yes'.

The following table summarizes the aforementioned findings as well as deepens the understanding of the form of language choice on Facebook and Instagram account of Tourist Village Pujon Kidul Malang.

\begin{tabular}{|c|c|c|c|c|}
\hline No. & \begin{tabular}{|c|}
$\begin{array}{c}\text { Online Media } \\
\text { Category }\end{array}$ \\
\end{tabular} & $\begin{array}{c}\text { Data Number and } \\
\text { Context }\end{array}$ & $\begin{array}{c}\text { Language Choice Forms } \\
\text { used in the Interaction }\end{array}$ & Notes \\
\hline \multirow[t]{2}{*}{1.} & Facebook & $\begin{array}{l}\text { Data 1: The location's } \\
\text { view (uploaded on } \\
\text { March 16, 2018) }\end{array}$ & $\begin{array}{l}\text { 1. Indonesian } \\
\text { 2. Javanese } \\
\text { 3. Mixed languages: } \\
\text { Indonesian English and } \\
\text { Indonesian Javanese }\end{array}$ & $\begin{array}{l}3 \text { forms of language } \\
\text { choice in both status } \\
\text { and comments }\end{array}$ \\
\hline & & $\begin{array}{l}\text { Data 2: Promoting an } \\
\text { activity (uploaded on } \\
\text { April 3, 2018) }\end{array}$ & $\begin{array}{l}\text { 1. Mixed languages } \\
\text { (Javanese, Indonesian, } \\
\text { English) } \\
\text { 2. Indonesian }\end{array}$ & $\begin{array}{l}2 \text { forms of language } \\
\text { choice in both status } \\
\text { and comments }\end{array}$ \\
\hline & & $\begin{array}{l}\text { Data 3: Introducing } \\
\text { the guides (uploaded } \\
\text { on April 22, 2018) }\end{array}$ & $\begin{array}{l}\text { 1. A mixed of Indonesian } \\
\text { and English }\end{array}$ & $\begin{array}{l}1 \text { form of language } \\
\text { choice in status only, } \\
\text { comments unavailable }\end{array}$ \\
\hline
\end{tabular}




\begin{tabular}{|c|c|c|c|c|}
\hline & & $\begin{array}{l}\text { Data } \\
\text { Announcement } \\
\text { (uploaded on July 26, } \\
2018 \text { ) }\end{array}$ & $\begin{array}{l}\text { 1. A mixed of Indonesian } \\
\text { and English } \\
\text { 2. Indonesian } \\
\text { 3. English }\end{array}$ & $\begin{array}{l}3 \text { forms of language } \\
\text { choice in both status } \\
\text { and comments }\end{array}$ \\
\hline & & $\begin{array}{l}\text { Data 5: } \begin{array}{r}\text { Tourist } \\
\text { Facilities } \\
\text { (uploaded }\end{array} \\
\text { on January } \\
4,2019)\end{array}$ & $\begin{array}{l}\text { 1. A mixed of Indonesian } \\
\text { and English } \\
\text { 2. Indonesian } \\
\text { 3. Javanese }\end{array}$ & $\begin{array}{l}3 \text { forms of language } \\
\text { choice in both status } \\
\text { and comments }\end{array}$ \\
\hline & & $\begin{array}{l}\text { Data 6: Customer } \\
\text { service (uploaded on } \\
\text { January 20,2019) }\end{array}$ & 1. Indonesian & $\begin{array}{l}1 \text { form of language } \\
\text { choice in both status } \\
\text { and comment }\end{array}$ \\
\hline & & $\begin{array}{l}\text { Data 7: Closing } \\
\text { announcement (due to } \\
\text { COVID-19) (uploaded } \\
\text { on July 7, 2020) }\end{array}$ & $\begin{array}{l}\text { 1. A mixed of } 1 . \\
\text { Indonesian English and } \\
\text { 2. Indonesian Javanese } \\
\text { 2. Indonesian } \\
\text { 3. English }\end{array}$ & $\begin{array}{l}3 \text { forms of language } \\
\text { choice in both status } \\
\text { and comments }\end{array}$ \\
\hline \multirow[t]{5}{*}{2.} & Instagram & $\begin{array}{l}\text { Data 1: Appeal to } \\
\text { tourists (uploaded on } \\
\text { October 17, 2018) }\end{array}$ & $\begin{array}{l}\text { 1. Indonesian } \\
\text { 2. A mixed of Indonesian } \\
\text { and Javanese }\end{array}$ & $\begin{array}{l}2 \text { forms of language } \\
\text { choice in both caption } \\
\text { and comments }\end{array}$ \\
\hline & & $\begin{array}{l}\text { Data 2: Profile Video } \\
\text { (uploaded on May 28, } \\
\text { 2019) }\end{array}$ & $\begin{array}{l}\text { 1. A mixed of Indonesian } \\
\text { and English } \\
\text { 2. Indonesian } \\
\text { 3. Indonesian }\end{array}$ & $\begin{array}{l}3 \text { forms of language } \\
\text { choice in both caption } \\
\text { and comments }\end{array}$ \\
\hline & & $\begin{array}{l}\text { Data 3: Promotion } \\
\text { (uploaded on August } \\
\text { 16, 2019) } \\
\end{array}$ & 1. Indonesian & $\begin{array}{l}1 \text { form of language } \\
\text { choice in both caption } \\
\text { and comment }\end{array}$ \\
\hline & & $\begin{array}{l}\text { Data 4: Information } \\
\text { regarding the café's } \\
\text { temporary closing } \\
\text { (uploaded on June } 22, \\
2020 \text { ) }\end{array}$ & $\begin{array}{l}\text { 1. Javanese } \\
\text { 2. Indonesian } \\
\text { 3. A mixed of } 1 . \\
\text { Indonesian English and } \\
\text { 2. Indonesian Javanese }\end{array}$ & $\begin{array}{l}3 \text { forms of language } \\
\text { choice in both caption } \\
\text { and comments }\end{array}$ \\
\hline & & $\begin{array}{l}\text { Data 5: Tour's } \\
\text { Reopening } \\
\text { Information (uploaded } \\
\text { on August } 14,2020)\end{array}$ & $\begin{array}{l}\text { 1. A mixed of Indonesian } \\
\text { English, Indonesian } \\
\text { Javanese, and Javanese } \\
\text { English } \\
\text { 2. Indonesian } \\
\text { 3. Javanese }\end{array}$ & $\begin{array}{l}3 \text { forms of language } \\
\text { choice in both caption } \\
\text { and comments }\end{array}$ \\
\hline
\end{tabular}

\subsection{The Process of Online Media Interaction of Tourist Village Pujon Kidul Malang Community}

The process of online media interaction is surely different from face-to-face communication, as online interaction needs to utilize either written or visual media to help them convey their intention as well as engage towards other online users, especially those who have Facebook and Instagram accounts.

The use of languages within the interaction of tourism community at Tourist Village Pujon Kidul Malang is not restrained at all. In fact, Facebook and Instagram users who either act as the caption writer or commenters are allowed to be creative in using any languages. It is proven through a thorough analysis that there are many forms of language choice appearing in both the captions and the comments, such as Indonesian, Javanese, English, and mixed languages of those three. The combination varies from Indonesian Javanese, Indonesian English, as well as 
Javanese English. However, considering the type of language use, most users chose to opt for informal or colloquial language.

Moreover, the context in question here is the one surrounding the status or caption managed by the social media administrator of Tourist Village Pujon Kidul. It can be implied from the interaction between the administrator and the users who engaged in either platform that if the former posted interesting photos or status regarding the destination, other users would gather and responded to the posts as well. Therefore, interaction would proceed should there be any attractive contexts uploaded on either their Facebook or Instagram page.

Last but not least, the dialogue room, or the comment section, functions as the space where both the administrator of the accounts and the other users engage and communicate, especially those who have been following Tourist Village Pujon Kidul Facebook and Instagram accounts. The comment sections on both platforms serve as a helpful space for users to give advice or criticism, ask questions, tell stories, or convey a simple statement to the current situation at the tourist village. However, it is to be noted that most of the times, the administrator did not respond to people's comments on either Facebook or Instagram.

\section{Conclusion}

Based on the findings, it is safe to say that there are approximately four forms of language choice used on online media, especially both of Tourist Village Pujon Kidul Facebook and Instagram accounts. They include Indonesian, English, Javanese, and mixed of languages, which vary from Indonesian-Javanese, Indonesian-English, and Javanese-Indonesian.

Regarding the interaction process in between the administrator and other users, they are allowed to be creative with the language that they use. Such approach is beneficial for both parties as they are not restrained by languages when expressing their thoughts. In addition, creating engaging contexts in both status and captions will attract more people to take part in the interaction. Lastly, within the interaction process, the availability of dialogue room in the form of comment sections benefits the users to give suggestion and criticism, questions, stories, or any statements necessary to the situation at Tourist Village Pujon Kidul Malang.

\section{Suggestion}

In this particular study, researchers only focus on the form of language choice and the process of interaction, therefore lacking in the description surrounding the aspects of language variety. Therefore, it is advised for further research to center their attention towards language variety used by online media community.

\section{Acknowledgements}

We would like to thank to the Faculty of Cultural Studies Universitas Brawijaya Malang Indonesia, for funding this research, and also thank to the team of researchers who were cohesive for conducting this research. 


\section{References}

[1] H. Mardikantoro, "Bentuk Pergeseran Bahasa Jawa Masyarakat Samin dalam Ranah Keluarga," LITERA, vol. 11, no. 2, 2012.

[2] A. Ngalim, "Sosiolinguistik: Suatu Kajian Fungsional dan Analisisnya," Surakarta PBSID FKIP UMS, 2013.

[3] A. Chaer and L. Agustina, Sosiolinguistik: perkenalan awal. Penerbit PT Rineka Cipta, 2004.

[4] D. Crystal, A dictionary of linguistics and phonetics, vol. 30. John Wiley \& Sons, 2011.

[5] I. Khasanah, R. Rusmawati, K. Mauliddian, and A. N. R. Hakim, "Language Choice of Residents of Kampung Warna-Warni Malang to the Tourists," OKARA J. Bhs. dan Sastra, vol. 14, no. 2, pp. 174-189, 2020.

[6] B. M. T. Verdiana, "Virus Corona Merebak Hampir di Seluruh Dunia, Haruskah Tunda Rencana Perjalanan?," $\quad$ Liputan $2020 . \quad$ [Online]. https://www.liputan6.com/global/read/4195679/virus-corona-merebak-hampir-di-seluruh-duniaharuskah-tunda-rencana-perjalanan.

[7] A. Lidwina, "Pandemi Covid-19 yang Terlambat Diantisipasi Indonesia," Katadata.co.id, 2020. [Online]. Available: https://katadata.co.id/safrezifitra/analisisdata/5f126ee0cecdb/pandemicovid-19-yang-terlambat-diantisipasi-indonesia.

[8] D. Ramadhanti, "Characteristic Behaviour In Students Speech With Minangkabau Cultural Setting: Interactional Sosiolinguistics Approach (Wujud Perilaku Berkarakter Dalam Tuturan Siswa Berlatar Budaya Minangkabau: Tinjauan Sosiolinguistik Interaksional)," J. Gramatika J. Penelit. Pendidik. Bhs. dan Sastra Indones., vol. 4, pp. 290-303, 2018.

[9] D. Rahmawati and W. Anindhita, "Potensi Media Daring Menciptakan Komunitas Informasi Transnasional ASEAN," in Prosiding Seminar Nasional INDOCOMPAC, 2016.

[10] R. Nasrullah, "Media sosial: Perspektif komunikasi, budaya, dan sosioteknologi," Bandung: Simbiosa Rekatama Media, vol. 2016, p. 2017, 2015.

[11] W. Labov, Sociolinguistic patterns, no. 4. University of Pennsylvania press, 1973.

[12] R. Fasold, "The sociolinguistics of society. Ch. 6," Lang. Attitudes. Basil Blackwell, Oxford, 1984.

[13] S. M. Ervins Tripp, "Sociolinguistcs Rules of Address dalam JB Pride and Janet Holmes," Socioling. Sel. Read., 1972.

[14] L. Niswa and M. Mukhlish, "Pilihan Bahasa Dalam Masyarakat Multilingual di Kemujan Karimunjawa Jepara," Caraka, vol. 3, no. 2, pp. 110-126, 2017.

[15] J. Moleong Lexy, "Qualitative Research Methodology.” Bandung: PT Adolescent Rosdakarya Offset, 2007.

[16] T. M. J. Kesuma, "Pengantar (metode) penelitian bahasa," Yogyakarta: Carasvatibooks, 2007. 